\title{
MENSURATION IN EARLY MEDIEVAL BARCELONA
}

\author{
Philip J. Banks
}

In a study of two documents from the convent of Sant Pere de les Puelles published in 1947 together with J. M. Millàs Vallicrosa, Dr. Udina made an examination of the value of the dexter in eleventh century Barcelona'. Although brief, this is one of the few modern contributions to the study of linear measurement in early medieval Catalonia, for, in spite of a recent resurgence of interest in the style and production of the documents which make up the bulk of our source material for this period, there has been no detailed consideration of the subject in the last few decades ${ }^{2}$. The present contribution aims to pay homage to Dr. Udina both by reconsidering the range and value of

1 J.M. MiLl.AS VAllicrosa and F. Udina MARTORELL, «Dos documentos latino-hebraicos del Archivo del monasterio de San Pedro de las Puellas» in Sefarad 7, 1947, pp. 123-137, esp. p. 131.

2 Particulary, M. ZIMMERMAN, «Protocoles et préambules dans les documents catalans du $\mathrm{x}$ au XII sièclen in Mélanges de la Casa de Velázquez 51-79, 1975, and idem, «La datation des documents catalans du XX au XI1 siècle: un itinćraire politique» in Annales du Midi 93, 345-375, 1981, for document production.

A. DE BofARrul y BRocÃ, Historia Crítica de Cataluña, Barcelona 1876 vol. II, p. 453 and J. BALARI JovaNY, Origenes históricos de Cataluña (Sant Cugat del Vallès, $1964^{2}$ ) pp. 655-7, are useful introductions. 
the linear measurements used in early medieval Barcelona, particularly in the city and its suburbs, and to a lesser extent its territorium, and by broadening the scope of his note so as to examine the reasons for the appearance or non-appearance of measurements in the sources, the size of the house-plot and other properties to be found in the early medieval city, and finally the possible origins and development of these units.

Much of Dr. Udina's 1947 discussion was devoted to calculating the value of the dexter mentioned in a document of 1092 referring to the sale of two plots of land in the suburbs of Barcelona at Pou de Moranta ${ }^{3}$. Udina and Millàs came to the conclusion that in this case 1 dexter $=1$ Hebrew «qanim» $=1$ «cana", and that these units were subdivided into eight palms or spans, which would suggest a total length of about 1,6 metres ${ }^{4}$.

Various units of length are found in use in early medieval Barcelona, but the dexter is by far the most common. However, the interpretation of its value is by no means straightforward, for only a small percentage of documents contain linear measurements: in the case of the city and suburbs about thirty-six out of a total of approximately one thousand in the period prior to the year $1200^{5}$. In addition, that the value of the dexter was by no means constant is indicated by the appearance of a dexter maior on a number of occasions, particularly in the first quarter of the eleventh century, which implies both knowledge and use of a dexter minor ${ }^{6}$. Moreover, although a few equations of values have been recorded, these cannot be automatically transferred from one locality to another for even within the confines of the territorium of Barcelona different standards were some-

${ }^{3}$ Pou de Moranta was near the later church of Santa Anna, as the documentation from that church, now in the ADB, amply demonstrates.

4 Op. cit., p. 131.

5 These are listed in an appendix.

6 The dexter maior is mentioned in document 10, and the following, among other, referring to the territorium: ACA R. Borrell 26 (996); ibid. 36 (998); ibid. 45 (1000); ibid. 88 (1007); ACV C6 171 (1008); ASPP 13 (1009); LAEC II 58 159, Mas 366 (1017); AM SBB 1291 (1018). A dexter minor is recorded in LAEC I 175, Mas 354 (1016). 
times in use, as is suggested by the occurrence of a dextro Barchinone (1083) and a dexter de Provinciana (1142) referring to the area of present-day Hospitalet?

The majority of modern works give the value of the Barcelona "destre" as $\mathbf{2 . 7 9 6}$ metres, which contradicts the figure proposed by Millás and Udina, and it would seem apposite to reconsider the available evidences. In 1947 they pointed to the existence of al least eight spans in the dexter since one side of one of the properties undergoing sale was stated to be two «destres" ) and seven spans in length. Although it is true that subdivisions of more than seven spans are rarely found, a document of 1098 describes a property as having sides two «destres» less four spans in length ${ }^{9}$. There seems to be no logical reason for counting backwards to achieve the figure of one and a half «destres» or one «destre» and four spans, so there must have been cases when there were more than eight spans to the «destre».

This is substantiated by three eleventh century documents which give values for the dexter being used in each case. Unfortunately, each gives a slightly different value, and a fourth possibility can be proposed in addition, with the result that the most frequently valid length of the dexter can only be guessed at. The earliest, of 1031, records that et dextro unde fuit mensurata ipsa terra abet palmos XII et palmada $I^{10}$. Even if the value of the span is taken as being approximately twenty centimetres, the uncertain value of a palmada leaves an element of doubt, although it might be assumed that it was somewhat larger, with the end result that the dexter in question measured in excess of 2.6 metres. A comparable value might be proposed as a conse-

7 Dextro Barchinone in ACA Monacales Montalegre 55 (1083); de Provinciana in LAEC I 324 916, Mas 1526: the latter is cited by F. Carreras Candi, Geografia General de Catalunya: la Ciutat de Barcelona, Barcelona, s.f., p. 327.

${ }^{8}$ E. g. LLENSA DE GELCÉN, Breve historia de las medidas agrarias de la antigüedad y estudio particular de aquellas cuyo uso es tradicional en Cataluña, Barcelona 1952, p. 47: A. M. AlCover et al., Diccionari català-valencià-balear, Palma de Mallorca 1976, vol. 4 p. 238 s.v. "destre».

9 Appendix document 23.

10 ACA Berenguer Ramon I 89. 
quence of a dextrum que habet tredecim palmos legitimos (1090) ${ }^{11}$, while the third document (1045) indicates et habet ipso dextro palmos XIII legitimos, which suggests a slightly larger figure, close to the 2.796 metres suggested by later sources ${ }^{12}$. These same sources indicate that two measurements of the span were in common usage from the later Middle Ages onwards: the smaller at slightly under twenty centimetres, while the latter was equivalent to 23,3 centimetres $^{13}$. That the latter unit was also in usage in the eleventh century is suggested by a re-examination of the document studied by Millàs and Udina. The east side of the first plot sold is stated to be two «destres" and seven spans in the Latin version, while the Hebrew text is translated as «dos canas y media y un palmo». This would indicate that half a «qanim» or «destre» contained six spans, and a complete unit would therefore consist of twelve. Since twelve of the longer "pams de destre» constituted a standard «destre» of 2.796 metres, it is probably fairly safe to conclude that these units were in use in this document.

The subject is evidently confused, but in most cases one is probably justified in accepting the dexter as having the traditional value, although it seems clear that other standards were sometimes used, particularly in the first part of the eleventh century, and there is some evidence to suggest that the dexter may originally have been silightly longer, a point to which we must return at a later moment. The use of the word legitimos in the documents of 1045 and 1090, and others of the same period, is perhaps significant for it hints at the existence of some official yardstick by which the measurement could be checked. That measures of volume were exhibited in the market from an early date is well known ${ }^{14}$. The same was also true at a later date of linear

11 ADB SA Carpeta 3A, 6.

12 ACB 1-1-2259.

13 Llensa de Gelcén, op. cit., p. 47.

14 ACA Monacales Sant Cugat 92: Rius II 371 (1002): ADB DC(b) 21 (1010); both cited by P. Bonnassie, La Catalogne du milieu du X' à la fin du XI' siècle: croissance et mutations d'une société, Toulouse 1975, p. 429, n. 211. In 987 we find the mensura legitima de civitate Barchinona (ACB 1-2-1502). 
measurements since there are a number of references to the legitimus dexter porte urbis Barchinome's, and the appearance of ipsum dextrum que videtur esse mensuratum ad orientales portam iamdicte civitatis in a document of 1092 leaves little doubt that the gate in question was the one under the Castell Vell adjoining the market ${ }^{16}$. None of these references, however, are earlier than the later eleventh century and the date of standardization is vague, although it is possible to put forward a hypothesis derived from the evidence for the measurements of volume.

In this case, measurements were apparently standardized by the early eleventh century, if not beforehand. However, the upheavals of the second quarter of the century probably led to fluctuations, for the measures of individuals are recorded as being used to calculate, for example, the amount of grain being loaned, a clear indication fo the absence of public authority and a practice obviously open to abuse ${ }^{17}$. Nevertheless, from 1058 onwards there are frequent references to "new measures» of volume, suggesting either the alteration of the old standards, or, and perhaps more probably, the reinstatement of public authority by Count Ramon Berenguer I, which would be just one more aspect of the now well-known mid-eleventh century recovery of comital power. One may legitimately wonder whether the measures of length were exhibited in the market at the same time. Certainly, the variations visible beforehand disappear thereafter, for the last reference to the dexter maior is significantly of $1032^{18}$.

${ }^{15}$ e.g. ASPP 60 (1102).

16 LAEC I 61 130, Mas 1104. The standards exhibited at the Portaferrissa and the chapel of Santa Llucia (CARRERAS CANDI, op. cit., pp. 352-3) must have been of later date, in both cases after c. 1260.

${ }^{17}$ e.g. ACA RBI 66 (1029); ACA Monacales Sant Llorenç del Munt 120 (1038).

18 ad mensura nova de Barchinova: ACA RBI 229 (1058); AM SBB 1465 (1060); BC 2159 (1061); the old measure is mentioned in ACB DC(d) 120 (1062), while AM SBB, 1500 (1065) has ad mensuram grandem de mercato and LAEC IV 160376 , Mas 817 , of the same year, suggests that this large measure was used beyond Barcelona. The last reference to the dexter maior is in document 10 of the appendix. 
As a result, from the mid-eleventh century onwards, virtually the only units found in the context of Barcelona are the dexter, with its subdivision of the span. Although it had once been equally common, particularly in the tenth century, the cubit virtually disappears ${ }^{19}$, for it is found only once in the later eleventh century ${ }^{20}$. One can only assume that the traditional value of six cubits in a dexter, thus indicating a value of 46.6 centimetres for the cubit, which is supported by evidence from elsewhere in the country, is also acceptable in the context of the ci$t^{21}$. Only towards the end of the twelfth century the other units notably the "braça» and the "cana", make their appearance ${ }^{22}$.

This confusion over the value of units is particularly unfortunate for contemporaries obviously took them seriously. Why else express a measurement down to the last inch, as occurs in a number of cases? Moreover, there are references to the presence of judges, or at a later date «prohoms», to take or verify the measurements ${ }^{23}$, and on occasions when this could not be performed immediately blanks were left in the document to be completed at a later date. Inevitably, on some occasions this was never fulfilled and parchments with still incomplete spaces exist ${ }^{24}$. On another occasion the word dextros is found crossed

${ }^{19}$ Documents $1,5,9,10$.

${ }^{20}$ Document 22.

${ }^{21}$ CSC 19 46: Rius 1293 (993), ad dextro que habet cubitos VI. However, marginally larger dimensions are often cited: CSC 51187 Rius II 388, abet ipso dextro cubitos VI et una polegada; AD Medinaceli A.H.leg.103 (985), et de ipso dextro qui ipsa omnia fuerit mensurata, cubitos abet VT et oso I (cited in Glossarium Mediae Latinitatis Cataloniae, Barcelona 1979, fasc. 8, col. 917. In the area of Girona, six cubits and half a foot appears to have been the norm, although it is uncertain whether this cubit was of 46,6 centimetres or not: examples in ibid., cols. $317-9$.

${ }^{22}$ Documents 30 and 36.

${ }^{23}$ Especially in LAEC IV 1961 , Mas 1525 , where it is stated that the measurements were taken some time after after the original sale (1142).

${ }^{24}$ In ACB 1-2-147 (996), it is clear that the measurements were added at a later date becauses of the spaces left. In appendix document 3, the document was copied into the Libri Antiquitatum without the measurements because they had presumably never been added to the original, as was the case with ACV C6 171 (1008). 
out and replaced by cubitos, so there was a very conscious respect of the significance of the units ${ }^{25}$.

It is difficult to decide why so few documents contain measurements. Most can, however, be assigned to one of four categories, and, even though not all documents which might be placed in these categories contain measurements, they do; it seems, go some way towards explaining their appearance. In the first pla$\mathrm{ce}$, the use of measurements is a phenomenon which appears particularly in the tenth and early eleventh centuries, when the public authority of the judicial system inherited from the Visigothic period was still operative ${ }^{26}$. Although the Visigothic law-code did not state any obligation to record dimensions during a property transaction, or even any obligation to draw up a written deed of sale, it did emphasize the importance of boundary markers and property limits ${ }^{27}$, and it is as an extension to these concepts that one must consider the earliest measurements recorded $^{28}$.

Secondly, there was a substancial growth in the use of measurements in the closing years of the tenth century and the first few decades of the following one ${ }^{29}$. As far as can be seen from a cursory examination of published material, this phenomenon seems to be restricted to the Barcelona area, with a possible exten-

25 Document 5 .

${ }^{26}$ For the judicial system, BonNASSIE, op. cit., pp. 183-202. For the use of the Visigothic code, M. ZIMMERMAN, "L'usage du droit wisigothique en Catalogne du IX au XII sièclem in Mélanges de la casa de Velázquez 9, $1973 \mathrm{pp}$. 233-281; W. KIENAST, "La pervivencia del derecho godo en el sur de Francia y Cataluñan in Boletín de la Real Academia de Buenas Letras de Barcelona $35,1973-74$, pp. 265-295 and F. UDINA MARTOREL L, «El sedimento visigodo en la Cataluna condal» in Revista de Archivos, Bibliotecas y Museos ( $4^{4}$ serie) 77, 1974, pp. 565-581.

${ }^{27}$ P.D. KING, Law and society in the Visigothic Kingdom, Cambridge 1972, p. 209.

${ }^{28}$ In the few surviving Visigothic private charters area measurements are occasionally mentioned, but not linear ones: A. CANEllas López, Diplomática Hispano-Visigoda, Zaragoza 1979.

29 Thus in the first hundred documents of the ACA Ramon Borrell series (993-1012), no fewer than twenty-one documents contain linear measurements. 
sion into the Baix Llobregat and Vallès. It is tempting to relate this to a need to record limits particularly carefully in the aftermath of al-Mansur's attack, for, even though destruction of property may not have been as extensive as often claimed, written records did suffer in particular, and whereas in normal practice all deeds relating to a property were handed over to the owner on its sale or donation, in such circumstances this would have been impossible ${ }^{30}$.

This leads one to relate measurements with a third context. A noticeable proportion of documents containing them seem to refer to «now) states, that is properties carved out of an exiting block or the result fractioning an originally larger estate ${ }^{31}$. Once again, since the boundaries were not otherwise recorded in writing, and on some occasions may not have been clear on the ground, the inclusion of dimensions gave an additional degree of security for both parties.

The fourth and final grouping may also contain an element of security, for it involves the Jewish community. A substantial proportion of the documents containing measurements of the period after c. 1075 involve Jews. Although anti-Semitism was not a feature of the period, there may have been an element of distrust which encouraged Jews to insist on the inclusion of dimensions to make sure that their rights were doubly protected $^{32}$.

Other examples do not easily fall into any of these categories to judge by the evidence available and we can only assume that the boundaries were not immediately clear or there was a possibility of a future dispute ${ }^{33}$. With the increasing urbanisation of the city in the twelfth century and the consequent lack of oppor-

${ }^{30}$ For the effects of al-Mansur's raid, M. ROvirA i SOLA, «Notes documentals sobre alguns efectes de la presa de Barcelona per al-Mansur (985)" in Acta Historica et Archaeologica Mediaevalia 1, 1960, pp. 31-53, although the criticisms of G. Feliu, «Al-Mansur, Barcelona i Sant Cugat» in ibid., 3, 1982, pp. 49-54, are largely valid.

${ }^{31}$ e.g. documents $11,12,15,25,26,29,35,36$.

${ }^{32}$ e.g. documents 16 to 18,21 .

33 e.g. documents 1 to 10 . 
tunities to alter established property boundaries, however, measurements became increasingly rare, except in the case of newly urbanised estates on the fringes of the city or the conveyance of narrow strips of property to facilitate wall construction or access $^{34}$.

We must turn our attention to consider briefly the information that these measurements give us about the size of urban properties. Within the old Roman defences, the extent of our evidence is remarkably limited: one of the earliest documents from the city records a plot containing a House and yard adjoining the Comital Palace in $924^{35}$. In spite of the lack of pressure on building space at that date, it seems to have been remarkably small, measuring approximately eight by seven and a half metres. A second document with measurements refers to the projecting castellum on the south side of the Roman defences by the Regomir Gate: this property stood at the south-east angle and appears to have occupied one quarter of the castellum, if the dexter is correctly calculated at 2.796 metres $^{36}$. The dimensions of a small piece of an orchard sold by the monks of Ripoll in 1054 indicate a trapezoidal terrain, some 15 metres long by $4.2 \mathrm{~m}$ tapering to $2.8 \mathrm{~m}^{37}$. Two documents referring to the Miracle area, around the remains of the Roman temple, are of little interest, for they concern narrow strips for the construction of dividing walls, rather than true properties, although a third document from the same area is more informative, since

${ }^{34}$ e.g. documents 16, 20, 22, 24, 27, 31, 32, 33. Especially interesting is $\mathrm{n}^{\circ} 22$ in which it is specifically stated that street construction might be a potential aim of the canons. Moreover, this plot was immediately outside the Bishop's Gate, which is not mentioned in the sources until 1108 (ACA Real Patrimonio, Subsección de la Bailia, Clase $2^{\mathrm{a}}, \mathrm{A}^{\mathrm{c}} 8$, fol. $49 \mathrm{r},-\mathrm{v}$.), although the other three gates are frequently mentioned from the later tenth century onwards. Could it be that access through the gate was impeded until this street was cut in c. 1093? Other evidence suggests that the main north-south street, running from this gate towards Sant Jaume, was in fact partially blocked until a much laterdate.

35 Document 1.

36 Document 10.

${ }^{37}$ Document 11. 
it cites a house with a street frontage of one and three quarter

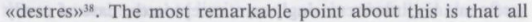
the available information leads one to identify it as the property now known as Carrer de la Freneria, $1^{39}$. A final document from the walled area tends to confirm the impression the previous document gives of long, relatively narrow plots, which can still be traced fronting onto the modern Carrer de la Llibreteria, for it describes an estate 3.9 metres wide but no less than 20.8 metres long ${ }^{40}$.

In the suburbs there is a small body of evidence which may have some bearing on house sizes: in 1028 a casalicium at the foot of the defences measured approximately eleven by nine metres. A second document, of 1082, is more significant: it describes an irregular quadrilateral with sides measuring approximately $20,30,26$ and 25 metres. Although it is not directly linked to the villanova, the fact the document is a lease by Bishop Umbert and the canons of land ad faciendum ortos vel ad faciendum domos suggests that this property should be connected with this area of planned growth which was developed under the auspices of the cathedral community from c. 1080 onwards. Although irregular, the size of the plot certainly fits comfortably between two of the north-south streets of this area, such as Carrer dels Banys Vells and Carrer de Montcada, and the regular eastwest property divisions still traceable today ${ }^{41}$. A similar case of measurements being provided zone is found in the early thirteenth in a newly urbanized zone in the Ribera district between

38 Document 34.

39 This subject is considered along with the topography of the Cathedral quarter in the eleventh and twelfth centuries in a forthcoming article of mine, "L'entorn de la catedral romànica de Barcelona».

${ }^{40}$ Document 35 : it is difficult to locate this property because of the variable position of north in the area around the Castell Vell. However, it was most probably ant the angle of Baixada de la Presó and Carrer del Veguer.

$4 \mathrm{I}$ The development of this villanova is discussed in BANKS, The topography of the city of Barcelona and its urban context in eastern Catalonia from the third to the twelfth centuries (Unpublished Ph.D. thesis, University of Nottingham, 1980) vol. II, pp. 612-623. 
Santa Maria del Mar and the sea, where a primary division is declared to be eleven by seven «destres», and a secondary one three «destres» in width ${ }^{42}$. The former set of dimensions might be identified as delimiting the block now surround by Carrer de l'Esparteria, Carrer de la Vidreria, Plaça de les Olles and Carrer Damas or one of the adjoining blocks.

There are two sets of measurements for yards alone, one of about 6.5 metres square and the other about 16.5 by 11 metres $^{43}$. The bulk of the rest of the recorded measurements refer to orchards: these vary widely in size, from a minimum of about 120 square metres to a maximun of over 800 square metres, with a median of around 200 square metres ${ }^{44}$. Later examples appear to be smaller than those of the late tenth century or early eleventh century, although the size of the sample must leave any conclusion open to doubt. Undefined plots of land could be of similar size or much larger, over a hectare on occasions. Once again, the measurements in this last category occasionally enable us to demonstrate that modern day street lines were in existence as property boundaries nearly a thousand years ago $\mathrm{g}^{45}$.

In the territorium, three main groupings of properties can be proposed on the basis of the evidence of measurements. First of all, long strips, found particulary on slopes ${ }^{46}$. Secondly, irregular quadrilaterals of varying size ${ }^{47}$, and thirdly, plots which can be defined as being more or less rectangular in shape. This last category, which comprises about seventy percent of the total,

42 ACA Diversos Sentmenat Indice 8 no. 20 and Indice 1 , nos. 2 and 3 (1209-10).

43 Documents 5 and 28.

44 Documents 2, 3, 6, 8, 17, 18, 19, 21, 23, 26.

45 Documents $4,12,13,15,29$. No. 13 is the most interesting because its preambulations and strange shape make it easy to identify as the area now to the north-east of the Capilla d'en Marcus.

46 e.g. ACA Monacales Sant Llorenç del Munt nos. 56 and 58 (1010-11) referring to $1001 / 2$ edestres» of vineyard at Monterols, or ACA Berenguer Ramon I, 118 (1035) describing a strip of land 75 "destres» by 9 «destres» and 4 spans at Provençals.

47 e.g. ACA R. BORRELL 45 (1000) measuring 133, 152, 55 and 88 «destres», or ibid. 63 (1002) with sides of 85 d.1c., $110 \mathrm{~d}$., $99 \mathrm{~d} .1 \mathrm{c}$, and $85 \mathrm{~d}$.. 
can be divided into two sub-groups: those which were relatively small in size, under eight «destres» square, and thus comparable to large «horts»; and those which were larger, but still basically rectangular in plan. These might be anything from five hundred square metres to five hectares in area, although an average would appear to be about half a hectare, in other words the modiata ( $=4896$ square metres) of the contemporary sources ${ }^{48}$.

This is of some importance for the modiata, which, together with its fractions, was the principal unit of area measurement, can be defined as a square with sides twenty five «destres» in length ${ }^{49}$. Moreover, of thirty-three rectangular plots documented with measurements in the Pla de Barcelona in the period prior to 1055 , two thirds have at least one figure, and almost as often two, which can be considered a fraction or multiple of twentyfive, allowing for a variation of four percent in either direction $^{50}$. Although there is no known example of a strictly regular twenty-five dexter square in this area, one can point to an example recorded in Cervelló in $976^{51}$.

Both the dexter and the modiata would appear to be units of early medieval origins, largely connected with the north-west Mediterranean littoral $^{52}$ : they certainly have no direct classical counterparts. However, given that it is unlikely that any extensi-

48 This is based on the evidence of forty-six pre-1055 documents with measurements referring to the territorium of Barcelona. Far more charters, of course, describe the property undergoing transaction in terms of area measurements, although in most cases one must assume that these were at best approximations.

${ }^{49}$ LLENSA DE GELCÉN, op. cit., p. 61: Alcover et al., op. cit., vol. 7 p. 640 , s.v. «mujada».

50 i.e. $12-13,24-26,36-39,48-52$ «destres».

51 ACA Monacales, Sant Cugat 45, Rius I 118, 976.

52 J.F. NIERMEYER, Mediae latinatis lexicon minus, Leiden 1954-76, p. 328 and 699 for southern French examples. While the etymology of dexter is obscure, that of the modiata is clearly related to the area that could be sown with a modius of seed, even though the measurement was later used of vineyards and other non-arable land and came to be considered as the area that could be ploughed in one day. It is particularly unfortunate that the work of the monk Oliba of Ripoll entitled De ponderibus at mensuris, which was seen by 
ve regular land division occurred in the period between the late Empire and the tenth century, one should perhaps look back to Antiquity in an attempt to trace the possible origins of these apparently recurrent lengths of approximately $35,70,105$ and 140 metres. One of the most common units of Roman land holding, both in Spain and elsewhere was the two iugera or one heredium division, equivalent to approximately 5036 square metres, although this could vary and depended on the length of the foot used. This area could be defined as a square of sides two actus (= 240 Roman feet) in length, and certainly the presence of blocks of a hundred of these squares, in other words a twenty actus grid, constitutes to this day the clearest proof of Roman centuriation, particularly of the Augustan period ${ }^{53}$. As recent research on the subject of centuriation has demonstrated, the subdivisions of these twenty actus blocks could be very varied, although rarely were parcels more than two heredia in size found $^{54}$. In view of the lack of adquate cartographical evidence for field boundaries in the Pla de Barcelona before the expansion of the city, it is difficult to envisage the day when it might be feasible to demonstrate the existence or extent of centuriation around the colonia Barcino through normal techniques, although it might be assumed that it existed, as in the case of

J. VillanueVA, (Viaje literario a las iglesias de España, Madrid, 1803-52, vol. VIII p. 55), was lost in the course of the nineteenth century, as it was obviously written at a crucial moment in the development of Catalan weights and measures.

53 O.A.W. DILKE, The Roman land surveyors: an introduction to the agrimensores, Newton Abbot 1971, p. 84, Universidad Autónoma de Madrid, Estudios sobre centuriaciones en España, Madrid, 1974, pp. 14-15, F. FAvORY, "Propositions pour une modélisation des cadastres ruraux antiques» in $\mathrm{M}$. Clavel-Lévêque (ed.), Cadastres et espace rural, Paris 1983, pp. 51-135, p. 80.

${ }^{54}$ FAVORY, op. cit., pp. 132-133 for Tunisian examples.

Also of interest is M. Guy, «Existence de bornages divisionnaires dans une centuriation antique» in M. CLAVEL-LÉVÊQUE, op. cit., pp. 315-313, referring to possibly ancient field boundary stones south of Ampurias set at intervals of $17 / 18,35$, and metres, i.e. $1 / 2,1$ and 2 actus (or approximately $6.25,12.5$ and 25 "destres»). 
most coloniae. Nevertheless, it is interesting to speculate on the possibility that the frequent twenty-five dexter measurements noted above might be a reflection of Roman two actus divisions. There are, however, a number of obstacles: in the first place there is clearly a slight difference in size between two actus (a minimum of $70,3 \mathrm{~m}$ with a standard of $70,968 \mathrm{~m}$ ) and twentyfive «destres» $(69,9 \mathrm{~m})$, if the eleventh century standard of $2,796 \mathrm{~m}$ is used. Secondly, there is as yet little comparative evidence from the Conventus Tarraconensis for centuriation, and there is no guarantee that the units found elsewhere in Hispania need ever haver been applied to this region. Thirdly, very few of the measurement are exactly fractions or multiples of twenty-five.

On the other hand, it might be argued that the difference between the units is in fact minimal, especially since the figures expressed in most of the charters were clearly to the nearest dexter, except in the case of small plots. Secondly, tenth century figures from other parts of Catalonia suggest that the «destre» may have once been slightly longer than the 2,796 m later accepted as standard"s. The objection concerning the rarity of absolutely regular measurements might be countered by arguing that minor changes of a few metres could easily have taken place in the preceding millenium, especially if the intensity of cultivation declined in the post-Roman period, as seems only logical ${ }^{56}$, Moreover, allowance must be made for field boundaries and paths between plots, which may or may not have been included within the dimensions recorded. It should also be noted that in most

55 See the references supra note 21. ACA R. BORRELL. 5 (993) states id est modiatas IIII ad dextro anteriore, thereby implying a relatively recent change in the value of the dexter.

${ }^{56}$ A number of early documents from the territorium refer to uncultivated land: e.g. E. Junyent, Diplomatari de la Catedral de Vic, fasc. 1, Vic 1980. no. 44 , pp. 41-2 (908). For other parallels between the late Roman period and the early medieval centuries, P.J. Bancks, "The Roman inheritance and topographical transitions in carly medieval Barcelona» in T.F.C. BLAGG, R.F.J. Jones and S.J. LEAY (eds.), Papers in Iberian Archaeology BAR IS 193, Oxford 1984, pp. 600-634. 
areas in Europe where centuriation can still be traced, relatively little of the layout can be established in detail nowadays, and it is only through the examination of extensive areas that patterns emerge more clearly. In most areas where cultivation has been more or less continuous from Antiquity onwards, it is clear that not only have changes occurred in the recent past, but also the original divisions had already undergone the sort of changes apparently visible in the Barcelona documentation by the end of the first millenium.

One final point might serve to associate the late tenth-early eleventh century modiata with a classical root and explain the diversity of units employed at that date. The monastery of Ripoll was renowned for its learning in tenth century Europe and among the works to be found in its library were copies of the Roman agrimensores' treatises ${ }^{57}$. Since the vast majority of the documents recording dimensions of agricultural plots belong to the two decades after c. 990, when activity at Ripoll was at its peak, could it be that one of the side effects of this activity was the increased use of measurements in contemporary private charters? If so, this may have led to the standardization of customary measures to reflect Roman regularity rather than strict accuracy, so that one dexter came to be considered the same as six cubits, twelve «pams de destre» or fourteen spans. Thus while the earlier, tenth century dexter was perhaps a slightly larger unit, which may have in fact been exactly one twenty-fifth of a two actus length, although this was probably not realised by contemporaries, its eleventh century namesake may have been reduced in size (dexter minor) so that it no longer consisted of six cubits plus a fraction of another unit, in an attempt to present

57 R. BEER, «Los manuscritos del Monastir de Santa María de Ripoll», Butlleti de la Reial Academia de Bones Lletres de Barcelona 5, 1909, 137-170, 230-280, 299-320, 329-365 and 492-520: J.M. Millàs VAllicrosA, Assaig d'història de les idees físiques i matemàtiques a la Catalunya medieval, Barcelona 1931, esp. pp. 214.9, 302-4 and 327-334, referring to ACA Ms, Ripoll.106. Most recently, with very full bibliography, L. TONEATTO, eTradition manuscrite et éditions modernes du Corpus Agrimensorum Romanorum» in M. Clavel-Lévêque, op. cit., pp. 21-50. 
a neat mathematical equation in the classical mould. The confused terminology of the period 990 to 1030 could, therefore, have reflected the overlap of the two systems, the dexter maior being the previous standard and the dexter minor the new yardstick.

This, however, is advancing into fields of extreme conjecture: in the absence of supporting evidence, suffice it to say that there does seem to be an emphasis on twenty-five dexter units in this period, and that these lengths may have been the result of the regular sub-division of Roman twenty actus centuriation blocks, for it is difficult to envisage any other moment at which such a regular division could have taken place. Needless to say, many other fields and vineyards present other measurements, thus reflecting the multitude of changes that had taken place ${ }^{58}$.

To conclude, six points can be made:

a) The dexter was in use from the early tenth century, if not before.

b) By the year 1050, the later traditional value of 2,796 metres appears to have been standard, at least in the Barcelona area, although beforehand a longer length seems feasible if not demonstrable.

c) A standard was exhibited in the market place alongside measures of volume.

d) The measurements recorded can occasionally help to demonstrate that certain blocks in the city of Barcelona have changed little in shape since the early Middle Ages.

e) Measurements were only recorded in charters when some doubt about the extent of the property was likely to arise.

${ }^{58}$ It should also be noted that many, if not all, the twenty-five dexter units come from the area of Provençals, which has on occasions been equated with the Roman ager provincialis (e.g. CARRERAS CANDI, op. cit., pp. 62-64). However, since so much of the documentation for this period is derived from the family archive of Vivas of Provençals, for which see P. BONNASsiE, «Une famille de la campagne barcelonaise et ses activités économiques aux alentours de l'an mils in Annales du Midi 76, 1964, pp. 261-303, one should perhaps exercise caution until a wider body of evidence is considered. 
f) In the territorium a case can be made for linking the frequently found fractions and multiples of twenty-five «destres» to Roman centuriation patterns.

\section{APPENDIX 1}

Barcelona documents weith measurements, 924-1200.

\section{Abbreviations}

ACA: Arxiu de la Corona d'Aragó: Cancelleria (unless otherwise stated)

R. Borrell: Parchments of Ramon Borrell

RBI: $\quad$ Parchments of Ramon Berenguer I

ACB: Arxiu Capitular de Barcelona: followed by parchment number

DC: Diversorum C

ACV: Arxiu Capitular de Vic

C6: $\quad$ Calaix 6

Lib.Dot.: Liber Dotationum

ADB: Arxiu Diocesà de Barcelona

ME: Mensa Episcopal

SA: Santa Anna

AMSBB Arxiu de Montserrat: Parchments of Sant Benet de Bages

ASPP: Arxiu de Sant Pere de les Puelles

BC: Biblioteca de Catalunya: parchments

CSC: Cartulario de Sant Cugat (in ACA) followed by reference to J. Rius Serra, Cartulario de aSant Cugat” del Vallès (Barcelona, 1945-47), 3 volumes.

LAEC: Libri Antiquitatum Ecclesie Cathedralis (in $\mathrm{ACB}$ ) followed by reference to J. Mas, Notes històriques del Bisbat de Barcelona, volumes IX-XII (Barcelona, 1900-14).
d.: dextros
c.: cubitos
p.: palmos. 


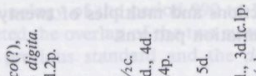
हैํํำ

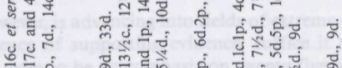

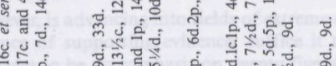

这

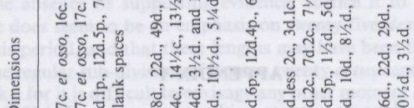

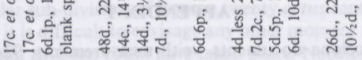

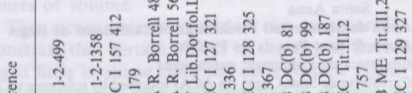

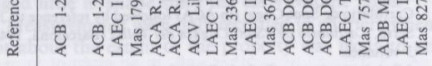

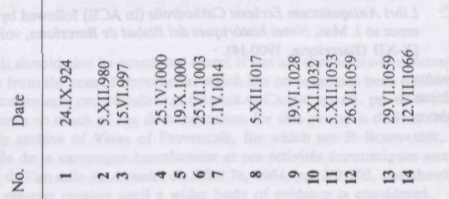




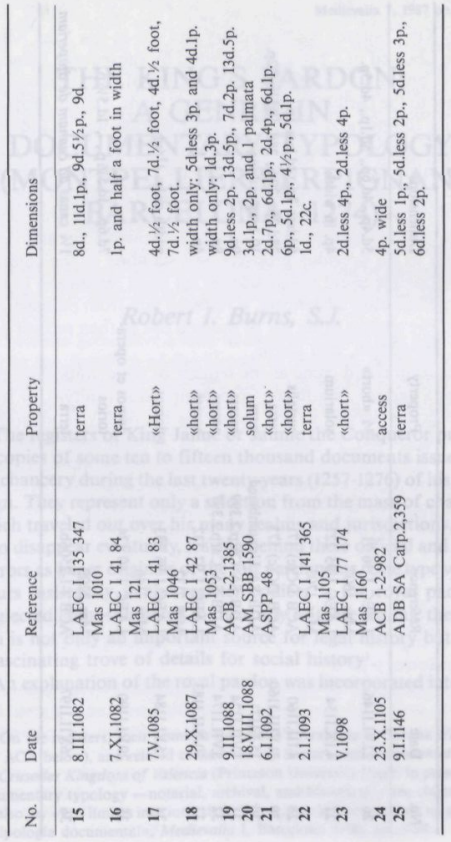




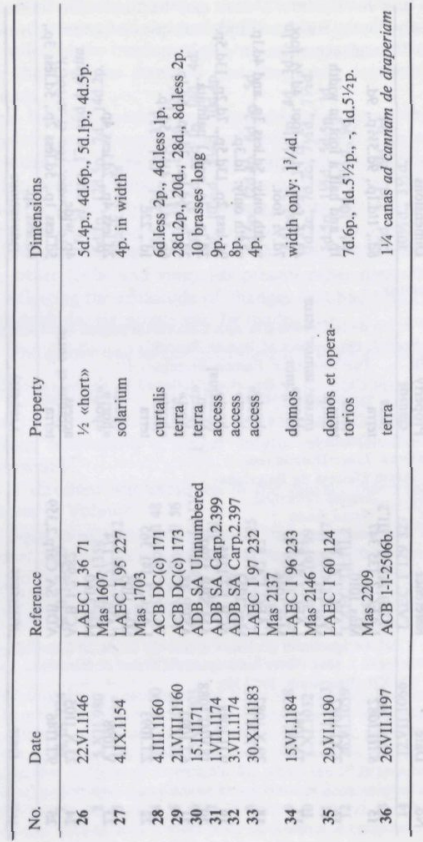

